\title{
Claim Settlement Process of Life Insurance Policies in Insurance Services - A Comparative Study of LIC of India and ICICI Prudential Life Insurance Company
}

\author{
Rajesh K. Yadav ${ }^{1 *}$, Sarvesh Mohania ${ }^{2}$ \\ ${ }^{1}$ Training \& Placement, Maxim Institute of Technology, Bhopal (M.P.), India \\ ${ }^{2}$ CRIM (UTD), Barkatullah University, Bhopal (M.P.), India; \\ *Email address: sarveshmohania@yahoo.com
}

\begin{abstract}
For the purpose of covering up financial risk along with better return on the investment, Life insurance coverage is taken up. Claims are filed at the time of maturity or in case of death/disability. The study focuses on the claim settlement process of life insurance services of LIC of India and ICICI prudential life insurance company. With the increasing market due to increasing number of policies, numbers of claims are also increasing in both the companies. Therefore it is very much essential to have simple and clear claim settlement process. The study is based on the secondary data collected from IRDA and research papers from various journals. The study concluded that in both LIC of India and ICICI prudential life insurance company are following proper claim settlement process.LIC of India claim settlement process is very much efficient but not that transparent and approachable as claim settlement process of ICICI Prudential Life Insurance Company. ICICI Prudential Life Insurance Company with their preference to customers, setting standards by claim settlement process and continues to lead private life insurance sector.
\end{abstract}

Keywords: Claim Settlement; Life Insurance; LIC of India and ICICI Prudential Life Insurance Company

\section{INTRODUCTION}

In order to get protection against economical loss arising due to an unexpected event, Insurance coverage is taken up. Insurance contract is a contract by which one party called the insurer who promises to save the other party, the insured on payment of consideration known as the premium. A right of insured to receive the amount secured under the policy of insurance contract promised by insurer is called claim. Claims can be maturity claims arise because of survival up to the end of the policy term i.e. to the date of maturity, survival benefits due to survival up to a specified period during the term, death claims arise due to death of the life assured during the term. Policy holders or nominees must first file an insurance claim before any money can be provided. An insurance claim is provided by an insurance company . The insurance company may or may not approve the claim, based on their own assessment of the condition under which claim is made. Claim settlement is one of 
the most important part of life insurance services. It is said that really testing of any insurance is done at the time of the claims. Any policyholder expects to have fair and hassle free claim settlement process at the time of need. Claim settlement process normally involves multiple systems, multiple processes, and multiple channels. Today insurance companies have improved their claim settlement process, controlled claim expenses and focuses towards improving customer satisfaction. LIC of India is the leading life insurance provider in India, having a large base of customer and agents. ICICI prudential life insurance company is one of the first private life insurance company set up in India in December 2000 and maintaining its lead over private sector life insurance companies.

\section{LIFE INSURANCE IN INDIA}

In India, insurance business started 150 years ago. With the establishment of the Oriental Life insurance company in Calcutta, the business of life insurance in India was started in 1818. It was started by Mr. Bipin Behari Dasgupta and Europeans living in India were their primary customers. The first native insurance provider in India was formed in 1870 with the name Bombay Mutual Life Assurance Society. In 1938, Insurance Act was passed and department of insurance under the authority of superintendent of Insurance was established for the administration of the Insurance Act. In 1939 - 1955 uncovers absence of trust which was the foundation of life insurance business and nationalization got vital. LIC of India was formed in 1956 by an Act of parliament and is fully owned by Government of India. As on till date there are total 24 Life Insurance Companies in India. Life Insurance Corporation of India, ICICI Prudential Life Insurance Company, Bajaj Allianz Life Insurance Company, and HDFC Life Insurance Company Etc., are the few names of Public sector and Private sector companies. [6]

Life insurance is mainly taken for two objectives, first is for risk coverage and second is for the investment objective.

A. Risk coverage:

Lump sum payment is provided if specific event occurred.

B. Investment:

Money is invested with a motive of getting greater return.

Primary purpose of any insurance service is to provide risk against uncertainty. For this risk management, policy holder regularly pays insurance premium to the insurance providing company. However, the risk is intangible and rarely the need for risk coverage is felt by an individual customer, therefore an extra effort needed to make the customer understand the need for insurance. [11]

\section{LIFE INSURANCE CORPORATION OF INDIA}

Initially Indian insurance market was quite unorganized and lack behind in different areas of financial market, for this purpose Life Insurance Corporation of India (LIC) was established on $1^{\text {st }}$ September 1956, after the parliament of India passed the Life Insurance Corporation act on the $19^{\text {th }}$ of June 1956. Till 2000 it enjoyed a monopoly status and better known as synonymous of Life Insurance. LIC of India is one of India's leading financial institutions, offering complete financial solutions that cover every sphere of life, From 
commercial banking to stock broking to mutual funds to life insurance to investment banking, the group caters to the financials needs of individuals and corporate. Its customer base is approx. 23 crores which is the largest in terms of Insurance Company. LIC has hundred divisional offices and has established extensive training facilities at all levels. They have their own Management Development Institute, seven Zonal Training Centers and 35 Sales Training Centers. As on till date LIC's staff strength is of 1.24 Lakh employees and 2048 branches and over Eleven Lakh agents. It is the second biggest Real Estate Owner after Indian Railways. In terms of Claim settlement, $97 \%$ maturity claim settled on or before due date, due to its prompt claim settlement LIC of India is No.1 insurance company in the world in terms of claim paid. It has been started with the objectives of spreading Life insurance widely and in particular to the rural areas; to meet the various life insurance needs of the community that would arise in the changing social and economic environment.

\section{ICICI PRUDENTIAL LIFE INSURANCE COMPANY}

ICICI Prudential Life Insurance Company is one of India's leading private life insurance companies which provide insurance product range for individuals and groups. ICICI Prudential Life Insurance Company is a joint venture between ICICI Bank LTD, India's largest private sector bank; it is currently functioning in 19 countries, including Indiaand Prudential Plc. established in 1948 in London is an international retail financial services group having operation in Asia, United States and United Kingdom;it is one of the best retail financial services providers with approximately 25 million customers. It is leading life insurer in Asia with presences in the 12 markets which include locations like India, Hong Kong, Malaysia, Vietnam, Singapore, Philippines and Indonesia.In the ICICI Prudential Life Insurance Company, ICICI Bank Ltd. holds $74.00 \%$ and Prudential Plc. holds $26.00 \%$ of equity in the joint venture. ICICI Prudential Life Insurance Company after receiving approval from Insurance Regulatory Development Authority (IRDA) in December 2000 was amongst the first private sector Insurance companies to start their operation.

ICICI Prudential Life Insurance Company has a strong network of approximately 1,400 offices and over 1, 75,000 advisors as on till date. Customers have the advantage of customizing the plans. Its product portfolio includes solutions, which meet various customer needs such as Savings, Investment, Protection, Health and Pension.

\section{CLAIMS SETTLEMENT PROCESS OF LIFE INSURANCE CORPORATION OF INDIA}

The LIC of India has laid emphasis on prompt settlement of death as well as maturity claims. Claims are normally paid however if found any fraudulent then it is referred to claim committee operating in zonal offices and central offices. Claim settlement process is divided into three stages i.e. claim intimation, claim processing and claim payment.

\subsection{Claim Intimation}

In the case of any type of claims whether death, maturity, double accidental and disability benefit claim, LIC of India as insurer or insurance providing company must receive intimation regarding arising of the event.Intimation can be done through walking into the 
branch from where insurance policy has been taken or if possible them the sales agent of LIC of India from whom insurance policy is purchase, will take care of intimation of the event to the concern branch.

\subsection{Claim Processing}

\section{A. In case of Death Claims}

The death claim amount is payable in both conditions, when policy's premiums is paid up-to-date and where the death occurs within the days of grace. After receiving information regarding death of the Life Assured the Branch office required following things:

- Claim form A - Claimant's Statement giving details of the deceased and the claimant.

- Certified extract from Death Register

- Documentary proof of age, if age is not admitted

- Evidence of title to the deceased's estate if the policy is not nominated, assigned or issued under M.W.P. Act.

- $\quad$ Original Policy Document

The following additional forms are required if death occurs within three years from the date of risk or from date of revival/reinstatement:

- Claim Form B - Medical Attendant's Certificate to be completed by the Medical Attendant of the deceased during his/her last illness

- $\quad$ Claim Form B1 - if the life assured received treatment in a hospital

- Claim form B2 - to be completed by the Medical Attendant who treated the deceased life assured prior to his last illness

- $\quad$ Claim Form C - Certificate of Identity and burial or cremation to be completed and signed by a person of known character and responsibility

- Claim form E - Certificate by Employer if the assured was employed person.

- If death was due to accident or unnatural cause certified copies of the First Information Report (FIR), the Post-mortem report and Police Investigation Report. These additional forms are required at the time of investigation by the officials of the Corporation and to prove the genuineness of the claim.

\section{B. In case of Maturity Claims}

- Amount is payable at the end of the policy period when it is endowment type of policies, At least two months before the due date of payment the Branch which provide services to the policy intimate the policyholder by sending a letter informing the date on which the policy amount is payable. Discharged form duly filled is requested in return from the policyholder along with the all policy document. After receiving documents postdated cheque is sent by post so as to reach the policyholder before the due date.

- $\quad$ Plans like money back policies give periodical amount to the policyholders if premium due under the policies are paid up to the anniversary due for survival benefit. In cases where amount payable is less than up to Rs.60,000/-, cheques are released without calling for the discharge receipt or policy Document. However, in case of higher amounts discharge receipt or policy document is mandatory.[12] 


\section{In case of Double Accident Benefit Claims}

- Copy of Panchnama/ FIR/Inquest Report \& Post Mortem Report for accidental \& suicide cases

- If Life Assured was driving the vehicle at the time of accident then copy of Driving License (Applicable if "Accident and Disability Benefit Rider" is opted)

- $\quad$ Claim must be filed within 120 days.

\section{In case of Disability Benefit Claims}

In the case of disability benefit claims, there is provision for the waiver of future premiums of the insurance policy and extend disability benefits which consist of a monthly benefit payment as per policy terms and conditions. For claiming this benefit the important condition to fulfill is that there has to be complete and permanent disability which precludes him/her from earning any wage/compensation or profit as a result of the accident disability. [2]

\subsection{Claim Payment}

Initially payment of claims are done through account payee cheques, but due to changing time and for securing the claim payment, N.E.F.T (National electronic fund transfer) are majorly use now days. If all the required documents are submitted and there is no need of further investigation then normally claims are paid up in 30 days.

\section{CLAIM SETTLEMENT PROCESS OF ICICI PRUDENTIAL LIFE INSURANCE COMPANY}

With the "Customer First" approach, ICICI Prudential Life Insurance Company tries to fulfill promise of early claim settlement to every customer along with transparency and quickness. They gave emphasis on earliest payment of genuine and legitimate claims, for that they review their claim process time to time.Here also claim settlement process is divided into three stages i.e. claim intimation, claim processing and claim payment.

\subsection{Claim Intimation}

Policy Holder/Nominee intimate claims to the ICICI Prudential Life Company, Intimation can be done through following ways:

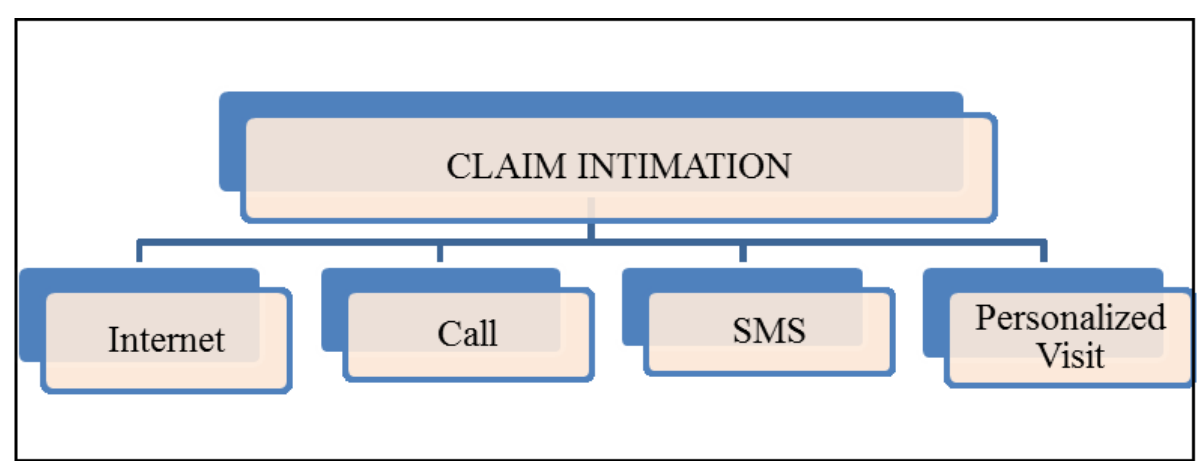

Fig. 1. Showing various mode of claim Intimation in ICICI Prudential Life Company. 


\section{- Through Internet}

Policy Holder/Nominee can intimate claims directly through the link available on the company's website. Claims registered through this mode are considered as verbal information which is not formally registered. For formally registering claims, one is required to file written intimation to concerned branch or to central claims team.

\section{ONLINE CLAIM INTIMATION}

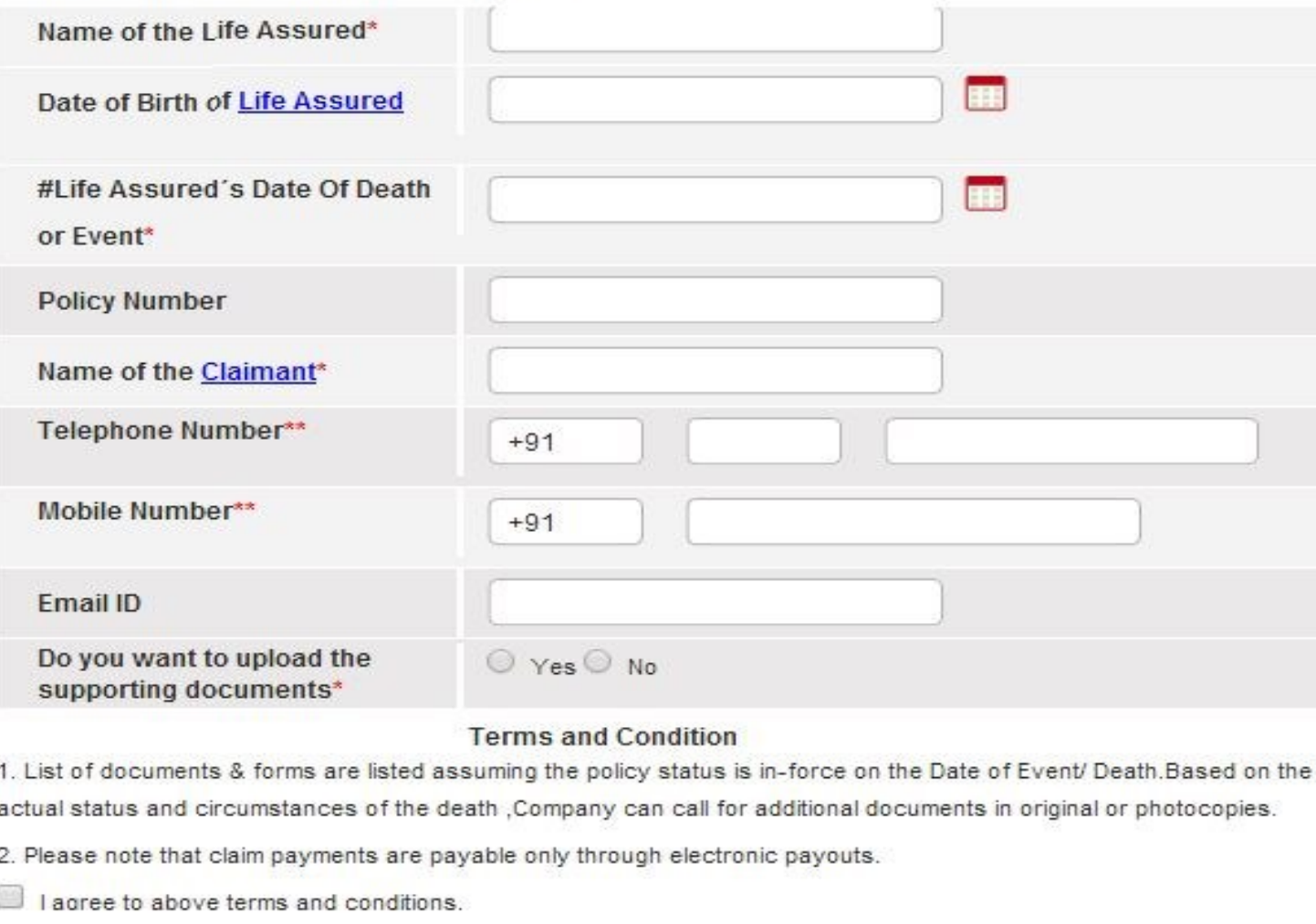

Fig. 2. Showing online mode of claim Intimation in ICICI Prudential Life Company. Source: https://onlinelifeinsurance.iciciprulife.com/digital/Others/ClaimIntimation.htm?execution=e1s1 .

\section{- Through Call}

Policy Holder/Nominee can intimate claims by calling on the available 24 X 7 customer care numbers. There are few toll free customer care numbers too. Claims registered through this mode are considered as verbal information which is not formally registered. For formally registering claims, one is required to file written intimation to concerned branch or to central claims team.

Toll-free No: - 1860-266-7766

\section{- Through personalized visit}

Policy Holder/Nominee can intimate claims to nearest branch of ICICI prudential Life Insurance Company or Corporate Claims Cell. Intimation should be in written form; this will be considered to formal intimation. There are more than 1400 numbers of branches all across in India. 


\section{- Through SMS}

Policy Holder/Nominee can intimate claims by sending SMS to IClaim Services along with policy number to 56767 . SMS IClaim $<$ space $>8$ digit policy no to 56767

\section{- Through e-mail}

Policy Holder/Nominee can intimate claims by sending e-mail to the dedicated e-mail address for claim settlement process.E-mail at lifeline@iciciprulife.com

\subsection{Claim Processing}

In claim processing, dedicated claim care team analyses each claim in detail. On the basis of all records and proofs in connection with the claim, Claims are examined and settled by the company. Sometime if there are any pending documents then the requirement is raised within 8 calendar days from the date of receipt of claim intimation, company informs the claimant about the required documentation. For the better services, customers are provided support during their claim settlement process and for that following features are added on :

- $\quad$ Priority Claim Desk at ICICI Prudential Life Insurance Company's branches.

- $\quad$ Sending SMS at specified milestones

- $\quad$ Personalized Calling

- Reminder letters if required any documents

- $\quad$ Sending e-mail to the claimants/beneficiaries.

- $\quad$ 24X 7 Claim helpline number 1860-266-7766.

\section{Document Submission}

The Policy holder/Nominee can submit all required documents at following :

- $\quad$ To the nearest ICICI Prudential Life Insurance Company branch

- $\quad$ Life claims cell / Health claims cell at:-

ICICI Prudential Life Insurance Company Ltd, BSEL tech, C- wing, 1st floor,

Vashi, Navi Mumbai - 400703.

\subsection{Claim Payment}

Once all the required documents are submitted to the concern branch or claim cell and documentation is complete then on the basis of that decision regarding the payment of claim is taken within 10 days. If in any case claims require further verification, the claimant is informed about that. Whatever a decision is taken, claimant is informed with the help of written communication through letter.[1]

\section{CONCLUSION}

Claim settlement process need to be as per requirement of the customers, so that at the time of need, no customer should be suffered due complexity of the claim settlement process.Faster claim settlement process reduces the cost of processing any claim whereas multiple stages in the process should be avoided since it increases the cost of claim 
settlement. For increasing the speed, policyholders should be provided proper information on regular bases. LIC of India is the oldest life insurance provider in India; adaptability is one of the major strength of this organization. In order to make claim settlement process more transparent and customer oriented, stress should be given on that. ICICI prudential life insurance company been newer than LIC of India,is very much flexible and they have updated their claim settlement as per the changing time and trend.

\section{References}

[1] Available from:- http://www.iciciprulife.com/public/Life-Claims/FAQ-claims.htm

[2] Available from:-https://www.licindia.in/policy_conditions.htm

[3] ChaudharySonika and KiranPriti, "Life Insurance Industry in India - Current Scenario", International Journal of Management \& Business Studies, Volume: 1, Issue: 3, (2011) pp. 146-150.

[4] KotgiriSushma K., "Growth of life Insurance Business: Public and Private Insurance Players in India”, Indian Journal of Research in Management, Business and Social Sciences, Volume: 1 Issue: 1, (2013) pp.62-66.

[5] Krishnan B., "Claims Management and Claims Settlements in Life Insurance", The Journal of Insurance Institute of India, Volume: XXXVI, (2010) pp. 49-57.

[6] Kumar Vineet and Kumari P., "A Comparative Study on Public vs. Private Sector in life Insurance in India", VSRD International Journal of Business and Management Research, Volume: 2, Issue: 10, (2012) pp. 515-517.

[7] Kumari T. H., "Performance Evaluation of Indian Life Insurance Industry in Post Liberalization", International Journal of Social Sciences Arts and Humanities, Volume: 1, Issue: 1, (2013) pp. 7-14.

[8] Purusothaman Uma R., "A Case Study on Growth of Investment in Life Insurance in India”, TRANS Asian Journal of Marketing \& Management Research, Volume: 2, Issue: 7, (2013) pp. 26-36.

[9] R. Nandagopal, J. Sekkizhar and Sathish M., "Customer Awareness With respect to ICICI Prudential Life Insurance Study with reference to Vellore", The Journal Contemporary Management Research, Volume: 5, Issue: 1, (2011) pp.59-67.

[10] Sharma Vikas and Chowhan Sudhinder S., "A Comparative Study of Public \& Private Life Insurance", Indian Journal of Applied Research, Volume: 1, Issue: 3, (2013) pp. 93-94. 
[11] Yadav Rajesh K. and Mohania Sarvesh, "Claim settlement of Life Insurance Policies in Insurance Services with Special Reference to Life Insurance Corporation of India", Indian Journal of Economics and Development; Volume 1, Issue 1: (2013) pp. 29-37.

[12] Yadav Rajesh K. and Mohania Sarvesh, "Claim settlement Process of Life Insurance Services - A Case Study of ICICI Prudential Life Insurance Company", International Letters of Social and Humanistic Sciences; 24(2014) pp. 26-32.

[13] Yadav Rajesh K., "Impact of Claim Settlement on Sales of Life Insurance Policies - A Case Study of LIC of India", International Letters of Social and Humanistic Sciences; 12(2014) pp.1-6. 